\title{
THE FOOD INVESTIGATION CALCULATOR, A USEFUL TOOL IN MEDICINE OFFICES FROM KINDERGARTENS
}

\author{
Dr. Ionescu Elena Teodora, \\ School Medical Office, Constanța
}

\begin{abstract}
:
OBJECTIVES: The Food Investigation Calculator was created due to the practical necessity to centralize and to interpret fast, efficient, correct and unitary the data showing the quantities of food consumed on average per day by the kids from kindergartens with an extended program with their own canteens.

METHODE: The Food Investigation Calculator is an Excel 2010 program that includes a data base with that characteristics of the food products (proteins, carbohydrates, calories and lipids), 10 daily worksheets and a statistic conclusion of the data registered in the in all 10 days of investigation.

RESULTS: It calculates the number of calories per child per day, the proteins, the carbohydrates and the lipids contained by the quantity of nourishment used to prepare food in that particular day. In the end, it centralizes all this data, giving information about the average ratios per child for 10 days and compares them to the estimated daily requirement provided in the tables of the legislation in force.

CONCLUSIONS: A correct and fast daily analysis of the quantitative and qualitative characteristics of the ingredients used in the preparation of food in the canteens of the kindergartens with extended program, leads to the remedy of the deviations in due time and to ensure a balanced diet among preschoolers.
\end{abstract}

KEY WORDS: food investigation, calculator, kindergartens

\section{Introduction}

Ensuring a balanced diet for children in schools is a major goal, for which a good collaboration be- tween the management and the medical staff in kindergartens is necessary. It is important to create a menu adapted qualitatively and quantitatively to the growth and development needs of children.

The quantitative analysis of the nutrition provided to children in kindergartens is carried out by conducting the food investigation, included in the attributions of the school medical staff and regulated by the following legislative acts $[1,2]$ that are in force:

- Order no. 1563/2008 issued by the Ministry of Health for the approval of the List of foods not recommended for preschoolers and school children and of the principles underlying a healthy diet for children and adolescents.

- Joint Order no.1668 / 5298/2011 issued by the Ministry of Education, Research, Youth and Sports and the Ministry of Health - for approving the Methodology on examining the health of preschoolers and students in state and private authorized / accredited educational institutions, on granting free health care and to promote a healthy lifestyle.

Thus, in M.H. Order nr. 1563/2008, Annex 4, art. 1 states: "For the assessment of the quantities of food consumed on average per day by a child, a calculation will be made based on food sheets taken out of storage daily, for a period of $\mathbf{1 0}$ working days (in two consecutive weeks) in February, May and October. The quantities from the food groups, cumulated on the 10 days, will be divided by the total number of consumers in the 10 days, obtaining the average ration per child, which will be compared with the recommended rations from table no. 1 "The estimated daily requirement of different food groups for a healthy diet in children and adolescents."

\footnotetext{
* Corresponding author: Elena Ionescu, medic Dispensar școlar Constanța, e-mail: elena_ionescu75@yahoo.com Article received: 09.01.2021, accepted: 30.01.2021, published: 12.04 .2021

Cite: Ionescu E. The food investigation calculator, a useful tool in medicine offices from kindergartens. The Journal of School and University Medicine 2021;VIII(1):14-18
} 
The M.E.R.Y.S. and M.H. Joint Order nr.1668/5298/2011 states the following:

"I. Attributions of the school doctor:

a) Approves the menus in kindergartens and school canteens.

b) Supervises the conduct of regular food investigations to verify compliance with a healthy diet."

"II. Attributions of the nurse:

a) Participates in the preparation of weekly menus and in the periodic conduct of investigations on the nutrition of preschoolers and students;

c) Assists in removing food from the warehouse and controls their organoleptic quality, signing the food sheet on food quality.

d) Checks daily the organoleptic properties of the food taken out of the warehouse and the functioning of the refrigerating units in the food block."

The quality of menus in kindergartens with extended program and the identification of methods to optimize these menus in accordance with the nutritional needs of preschoolers was analyzed in studies conducted by teams of professionals in Tg Mureș $[3,4,5]$. We further propose a computer program for quantitative analysis of menus, which can be done in all kindergartens in the country.

To carry out the food investigation, the following are needed: 10 consecutive storage sheets from October, February and May (quantities, in kilograms, of ingredients used to prepare food), the menu for the 10 days and the number of children present at the table.

In the vast majority of schools in the country, the recording and processing of this data is done using a pen / pencil, the calculation for each food taken out of the pantry is time consuming. For this reason, I propose the use of the Food Investigation Calculator, even if the resistance to change and the lack of equipment / computers of school medical offices are justified obstacles in its use.

\section{Program description:}

The Food Investigation Calculator is an Excel 2010 program consisting of 12 worksheets:

- The first worksheet is called "PRODUCT VALUES" and it is a database of 289 food products, containing the net quantity needed for preparing the meals, but also the composition per 100 grams in proteins (vegetal proteins, animal proteins, total proteins), lipids (vegetal, animal, total), carbohydrates, iron, calcium, calories, the group of aliments to which it belongs (i.e. milk and dairy products, vegetables, fruits, etc), and the coefficient of its food equivalent.

- 10 worksheets called „DAILY FILE”, numbered from 1 to 10 , the exact amount of days needed for the food investigation.

- The final worksheet is called "KINDERGARTEN FOOD INVESTIGATION" and it centralizes, based on pre-established formulas and data entered in the worksheets, all the information necessary to compare the results obtained with the ratios recommended by law.

It is important not to change the names of these sheets, as the calculation formulas will no longer work properly and the program will be compromised.

The characteristics of the products (proteins, lipids, carbohydrates, calories, etc.) were taken from the food labels, from the tables with these data published in specialized volumes [6,7], and from various specialized websites $[8,9]$. Other foods used in the canteen can be easily entered in the table by adding a new row or the data of an already introduced product can be modified according to the manufacturer's label.

The daily worksheet includes the following: the name of the kindergarten, the date, the daily menu and a table. The table shows: the number of children present at the table, the ingredients used to prepare the food and their quantity in kilograms (the rows in columns B and C). Of great help are the dropdowns that facilitate the quick selection of the food to be introduced. The computer will display the amount of protein, fat, carbohydrates and calories corresponding to each food, each child, but also separately on each meal (breakfast, snacks, lunch), as well as food equivalents, in kilograms, corresponding to the product group. There are 13 product groups (eg group 1: milk and dairy products in milk equivalent) [1]. In order to be able to calculate the calories on each meal, in column B the corresponding rows are numbered and marked with different colours (breakfast - red, snack at 10 o'clock - green, lunch - yellow, snack at 16 o'clock - blue). 
Journal of School and University Medicine

Image nr 1. "PRODUCT VALUES" worksheet

\begin{tabular}{|c|c|c|c|c|c|c|c|c|c|c|c|c|c|c|c|c|}
\hline $\begin{array}{l}\mathrm{Nr} \\
\mathrm{crt} .\end{array}$ & NUME ALIMENT & NET & $\begin{array}{l}\text { PROTEINE } \\
\text { VEGetale }\end{array}$ & $\begin{array}{l}\text { PROTEINE } \\
\text { ANIMALE }\end{array}$ & \begin{tabular}{|c|} 
PROTEINE \\
TOTALE
\end{tabular} & $\begin{array}{c}\text { UPIDE } \\
\text { VEGETALE }\end{array}$ & \begin{tabular}{|c|} 
IPIDE \\
ANIMALE
\end{tabular} & \begin{tabular}{|c|} 
UPIDE \\
TOTALE
\end{tabular} & GLUCIDE & $\begin{array}{l}\text { Fier } \\
(\mathrm{mg})\end{array}$ & $\begin{array}{l}\text { Calciu } \\
\text { (mg) }\end{array}$ & CALORII/100g & grup pre & & $\begin{array}{l}\text { coeficic } \\
\text { echivalc }\end{array}$ & \\
\hline 1 & ARDEI GRAS GALGEN & 0.73 & 1.1 & & 1.1 & 0.2 & & 0.2 & 4.6 & 0.43 & & 25 & 10 & & 1 & \\
\hline 2 & ARDEI GRAS ROȘU & 0.73 & 13 & & 1.3 & 0.4 & & 0.4 & 7.3 & 0.43 & 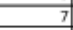 & 39 & 10 & & 1 & \\
\hline 3 & $\begin{array}{l}\text { ARDEI GRAS VERDE } \\
\end{array}$ & 0.73 & 1.1 & & 1.1 & 0.2 & & 0.2 & 4.6 & 0.43 & 7 & 25 & 10 & & 1 & \\
\hline 4 & ARDEI KAPIA & 0.75 & 0.99 & & 0.99 & 0.3 & & 0.3 & 6.03 & 0.43 & 7 & 26. & 10 & & 1 & \\
\hline 5 & BAME & 0.9 & 1.87 & & 1.87 & 0.21 & & 0.21 & 4.51 & 0.28 & 77 & 22 & 10 & & 2 & \\
\hline 6 & BANANE & 0.68 & 1.3 & & 1.3 & 0.4 & & 0.4 & 15.7 & 0.26 & 5 & 73 & 12 & & 1 & \\
\hline 7 & BATON & 1 & 7.83 & & 7.83 & 3.27 & & 3.27 & 57.06 & & & 296.4 & 8 & & 1 & \\
\hline 8 & BATON NESQUIK & 1 & 7.2 & & 7.2 & 13.6 & & 13.6 & 66.6 & & & 418 & 13 & 8 & 0.27 & 0.5 \\
\hline 9 & BISCUITI DE CAS & 1 & 9.8 & & 9.8 & 6.8 & & 6.8 & 78 & & & 392 & 8 & 13 & 0.7 & 0.2 \\
\hline 10 & BISCUITI CHOCO MINIS MILKA & 1 & 7.2 & & 7.2 & 24 & & 24 & 60 & & & 486 & 8 & 13 & 0.7 & 0.2 \\
\hline 11 & BISCUITI DIGESTA & 1 & 7.1 & & 7.1 & 22.5 & & 22.5 & 65.5 & & & 496 & 8 & 13 & 0.7 & 0.2 \\
\hline 12 & BISCUITI MAIA & 1 & 8.8 & & 8.8 & 9.2 & & 9.2 & 59.4 & & & 353 & 8 & 13 & 0.7 & 0.2 \\
\hline 13 & BISCUITI PICNIC & 1 & 13.4 & & 13.4 & 3.9 & & 3.9 & \begin{tabular}{c|c|}
60.7 \\
\end{tabular} & & & 346 & 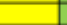 & & & \\
\hline 14 & BISCUITI POIENI & 1 & 6.6 & & 6.6 & 24.4 & & 24.4 & 65.5 & & & 446 & 8 & 13 & 0.7 & 0.2 \\
\hline 15 & BISCUITI OBISNUITI & 1 & 9 & & 9 & 9 & & 9 & 70.3 & & & 409 & 8 & 13 & 0.7 & 0.2 \\
\hline 16 & BISCUITI TEOI & 1 & 8.8 & & 8.8 & 3 & 3.5 & 6.5 & 71 & & & 441 & 8 & 13 & 0.7 & 0.2 \\
\hline 17 & BISCUITI BELVITA & 1 & 8.2 & & 8.2 & 16 & & 16 & 67 & & & 455 & 8 & 13 & 0.7 & 0.2 \\
\hline 18 & BOIA DE ARDEI DULCE & 1 & 14.14 & & 14.14 & 12.89 & & 12.89 & 53.29 & 21.14 & 229 & 282 & 10 & & 1 & \\
\hline 19 & BORS & 1 & 0.4 & & 0.4 & & & 0 & 0.6 & & & 4 & & & & \\
\hline 20 & BRĀNZŻ̆ DE BURDUF & 1 & & 24 & 24 & & 26 & 26 & 1.5 & 0.8 & 700 & 346 & 1 & & 4.5 & \\
\hline 21 & BRÄNZĀ DULCE DE VACĂ & 1 & & 11.12 & 11.12 & & 4.3 & 4.3 & 3.38 & 0.5 & 250 & 98 & 1 & & 4 & \\
\hline 22 & BRÄNZZ̈ MOZZARELLA & 1 & & 22.17 & 22,17 & & 22.14 & 22.14 & 2.4 & 0.44 & 505 & 299 & 1 & & 4 & \\
\hline 23 & BRÄNZZ̈ TELEMEA DE OO & 1 & & 10.9 & 10.9 & & 24 & 24 & 1 & 0.6 & 500 & 270 & 1 & & 4.5 & \\
\hline 24 & BRÄNZZ̈ TELEMEA DE VACÄ & 1 & & 17 & 17 & & 17.2 & 17.2 & 1 & 0.6 & 500 & 243 & 1 & & 5.5 & \\
\hline 25 & BRÁNZÄ TOPITÁ & 1 & & 11.2 & 11.2 & & 26.9 & 26.9 & 6 & 0.5 & 250 & 309 & 1 & & 7 & \\
\hline 26 & BRËNZZICX̆ ALMETTE & 1 & & 6 & 6 & & 26 & 26 & 3 & 0.5 & 250 & 270 & 1 & & 4 & \\
\hline 27 & 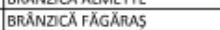 & 1 & & 11 & 11 & & 6 & $\frac{20}{6}$ & 3 & 0.5 & 250 & $\frac{96}{98}$ & $\frac{1}{1}$ & & 4 & \\
\hline 28 & BRÁNZZCÁ PHILADELPHIA & 1 & & 5.9 & 5.9 & & 26 & 26. & 3 & 0.5 & 250 & 270 & 1 & & 4 & \\
\hline 29 & BRANZOICA & 1 & 3 & 4.8 & 7.8 & 3 & 4.6 & 7.6 & 27 & & & 214 & 8 & 13 & 0.7 & 0.2 \\
\hline 30 & 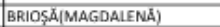 & 1 & 4 & 5.5 & 9.5 & 3 & 4.5 & 7.5 & 57.8 & 0.5 & 250 & 457 & 8 & 13 & 0.7 & 0.2 \\
\hline 31 & BRIOS $\bar{A}$ CU FULGI DE COCOS & 1 & 4 & 5.5 & 9.5 & 3 & 4.5 & 7.5 & 57.8 & 0.5 & 250 & 287.05 & 8 & 13 & 0.7 & 0.2 \\
\hline 32 & BROCOLI & 0.8 & 2.38 & & 2.38 & 0.41 & & 0.41 & 7.18 & 0.67 & 40 & 35 & 10 & & 1 & \\
\hline 33 & BROWNIE CU STAFIOE & 1 & 4 & 5.5 & 9.5 & 3 & 4.5 & 7.5 & 57.8 & 0.5 & 250 & 466.23 & & & & \\
\hline 34 & BULION & 1 & 2.7 & & 2.7 & 0.6 & & 0.6 & 8.3 & 2 & 70 & 51 & 10 & & 6 & \\
\hline
\end{tabular}

Image nr 2. "DAILY WORKSHEET"

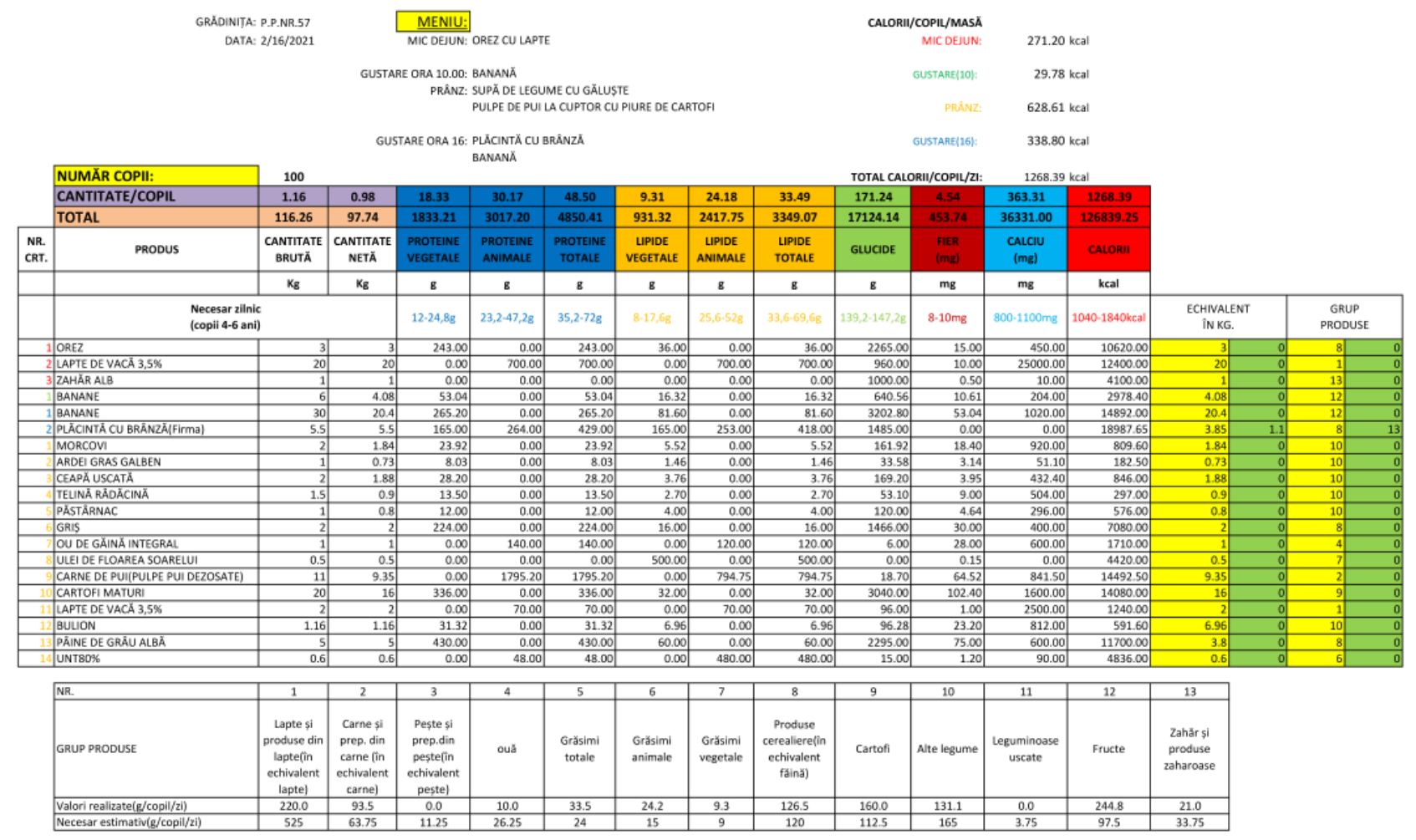


In the worksheet "KINDERGARTEN FOOD INVESTIGATION" the values achieved over 10 days are compared with the values recommended in the legislation [1], these values are interpreted and deviations from the average are calculated.

Image $\mathrm{nr}$ 3. Tables containing the values obtained over 10 days
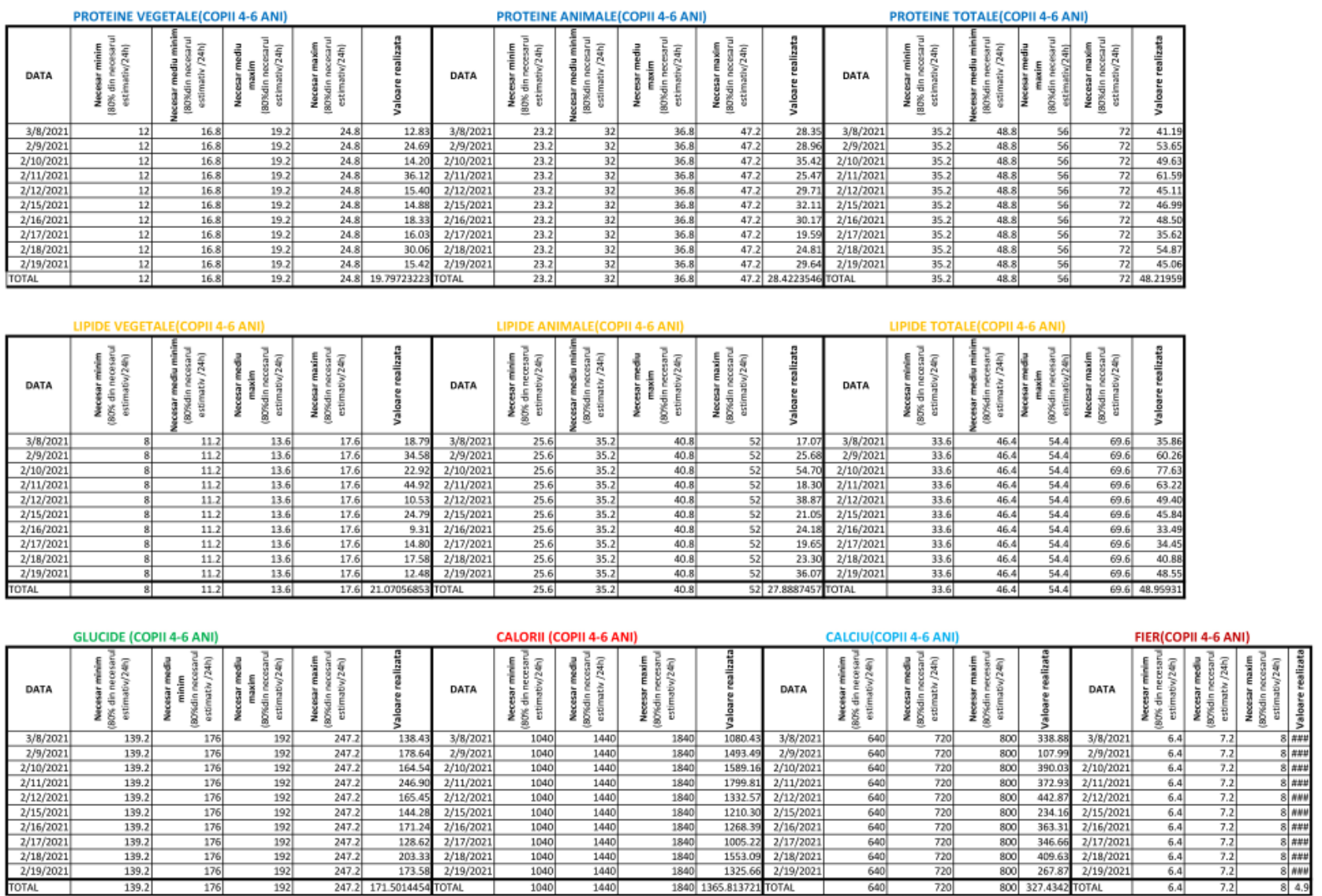

The worksheets as well as the conclusions of the food investigation can be printed and archived at the end of each month (October, February, May). The conclusions of the investigation are communicated to the kindergarten's principal, so that if major discrepancies are found proper corrective measures could be taken.
This program has the advantage that it can be used every day, so that, at any time, completing the 10 daily worksheets, we can have an image of compliance or not with the daily amounts recommended for children attending kindergarten. 
Image $\mathrm{nr}$ 4. Table containing the analyzed results and the deviations from the average
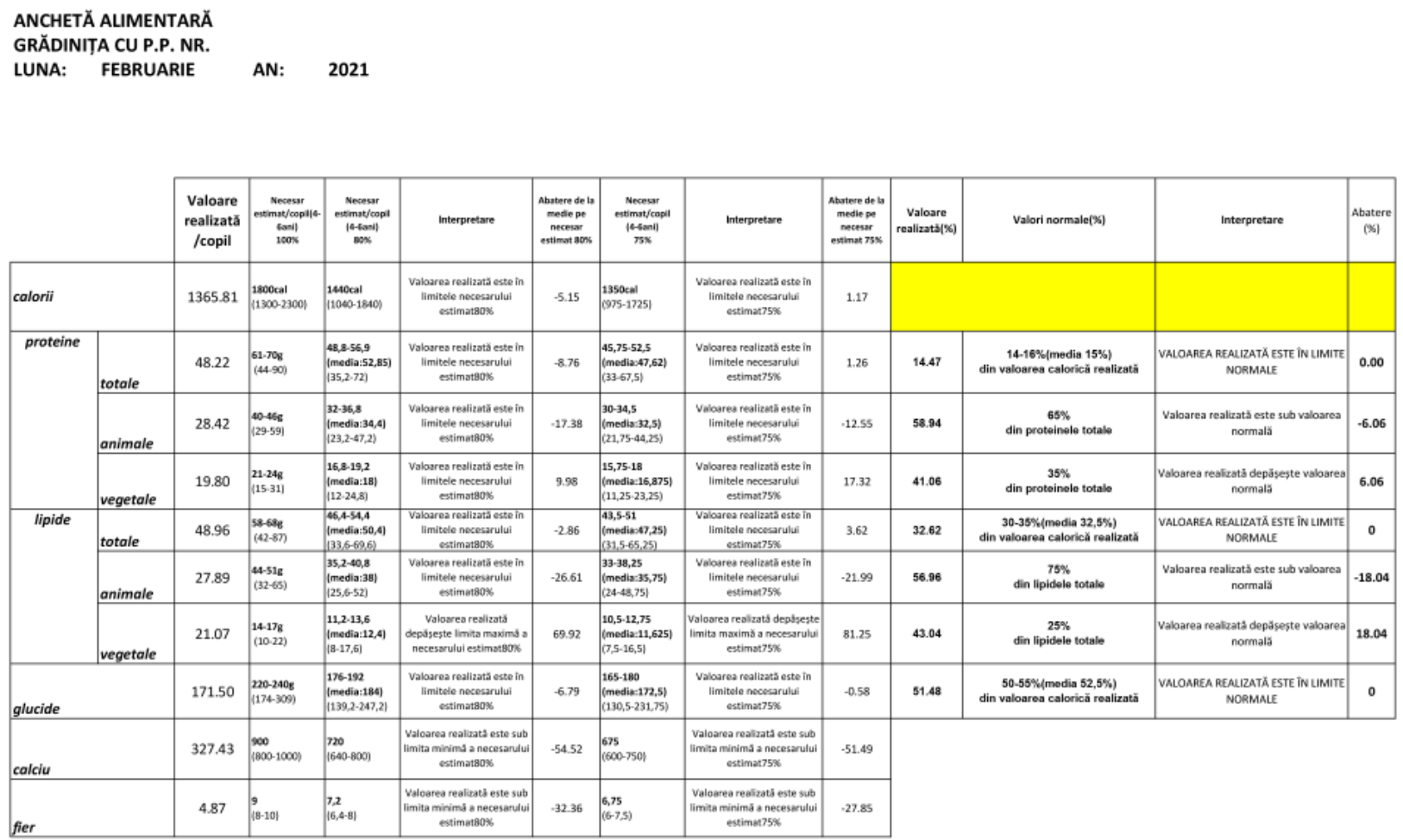

\section{Conclusions}

A correct and fast daily analysis of the quantitative and qualitative characteristics of the ingredients used in the preparation of food in the canteens of the kindergartens with extended program, leads to the remedy of the deviations in due time and to ensure a balanced diet among preschoolers.

The program can be downloaded from the "Download" section of the http://www.medicinascolara.ro website.

\section{References:}

1. Order - no. $1563 / 2008$ issued by the Ministry of Health for the approval of the List of foods not recommended for preschoolers and schoolchildren and the principles underlying a healthy diet for children and adolescents.

2. Joint Order - no.1668 / 5298/2011 issued by the Ministry of Education, Research, Youth and Sports and the Ministry of Health - for approving the Methodology on examining the health of preschoolers and students in authorized / accredi- ted state and private educational institutions, on granting free health care and to promote a healthy lifestyle.

3. Hadmas RM, Neghirlă A. Qualitative Analysis of Kindergartens Menus from Tg Mureș, Romania. Journal of School and University Medicine 2016;3(1):5-19

4. Hadmaș RM, Neghirlă A, Martin ȘA. Evolution of kindergartens` food plan, with and without dietetic intervention. Journal of School and University Medicine 2018;5(1):15-20

5. Hadmaș RM, Tarcea M, Neghirlă A, Mărginean O, Martin A, Martin ȘA. Nutritional value of kindergartens menus from Mures / Romania, related to national and international dietary recommendations. Medicine in evolution 2017; XXIII(3): 271-278

6. Andrei Antal. School hygiene, Theory and practice of promoting the health of children and young people in communities, second edition, Editura: Medicala, București,1978, pg.376-390

7. Gheorghe Eugeniu Bucur,Octavian Popescu. Health education in schools, 2nd edition, Editura: Fiat Lux,București,1999,pg.50-57.

8. https://calorii.oneden.com/

9. https://fdc.nal.usda.gov/ 